\title{
Tolpyralate + Atrazine Applied Preemergence Provides Residual GR Canada Fleabane [Conyza canadensis (L.) Cronq.] Control Similar to Current Industry Standards
}

\author{
Nicole M. Langdon'1, Nader Soltani ${ }^{1}$, Alan J. Raedar ${ }^{2}$, David C. Hooker ${ }^{1}$, \\ Darren E. Robinson'1, Peter H. Sikkema1 \\ ${ }^{1}$ University of Guelph Ridgetown Campus, Ridgetown, Canada \\ ${ }^{2}$ ISK Biosciences Inc., Concord, OH, USA \\ Email: *soltanin@uoguelph.ca
}

How to cite this paper: Langdon, N.M., Soltani, N., Raedar, A.J., Hooker, D.C., Robinson, D.E. and Sikkema, P.H. (2020) Tolpyralate + Atrazine Applied Preemergence Provides Residual GR Canada Fleabane [Conyza canadensis (L.) Cronq.] Control Similar to Current Industry Standards. Agricultural Sciences, 11, 417-424.

https://doi.org/10.4236/as.2020.114024

Received: February 28, 2020

Accepted: April 6, 2020

Published: April 9, 2020

Copyright $\odot 2020$ by author(s) and Scientific Research Publishing Inc. This work is licensed under the Creative Commons Attribution International License (CC BY 4.0).

http://creativecommons.org/licenses/by/4.0/

\begin{abstract}
Tolpyralate is a benzoylpyrazole, 4-hydroxyphenyl-pyruvate dioxygenase inhibitor, and a herbicide registered for use in corn. The efficacy of tolpyralate plus atrazine to provide full-season residual control of glyphosate-resistant (GR) Canada fleabane in corn is not known under Ontario environmental conditions. Five field trials were completed over a two-year period (2018-19) in south-western Ontario on farms with confirmed GR Canada fleabane [Conyza canadensis (L.) Cronq.] populations to determine if tolpyralate + atrazine provides full-season residual control of GR Canada fleabane in corn. Corn injury was less than $10 \%$ with all treatments. At 4 weeks after application (WAA), tolpyralate (30 g.ai $\left.\cdot \mathrm{ha}^{-1}\right)$, tolpyralate (40 g.ai $\left.\cdot \mathrm{ha}^{-1}\right)$, and atrazine $\left(560 \mathrm{~g} \cdot \mathrm{ai} \cdot \mathrm{ha}^{-1}\right.$ ) controlled GR Canada fleabane 64,78 and $72 \%$, respectively. A tank mix of tolpyralate + atrazine at both rates improved GR Canada fleabane control to $94 \%$. Saflufenacil/dimethenamid-p, mesotrione + atrazine, and dicamba/atrazine controlled GR Canada fleabane 99, 95 and 92\%, respectively. At 8 WAA, tolpyralate $\left(30 \mathrm{~g} \cdot a \mathrm{i} \cdot \mathrm{ha}^{-1}\right)$, tolpyralate $\left(40 \mathrm{~g} \cdot \mathrm{ai} \cdot \mathrm{ha}^{-1}\right)$ and atrazine (560 g.ai.ha ${ }^{-1}$ ) controlled GR Canada fleabane 83,88 , and $83 \%$, respectively (Table 2$)$. The tank mixes of tolpyralate $\left(30 \mathrm{~g} \cdot \mathrm{ai} \cdot \mathrm{ha}^{-1}\right)+$ atrazine (560 g.ai ha $\left.{ }^{-1}\right)$ and tolpyralate $\left(40 \mathrm{~g} \cdot a \mathrm{i} \cdot \mathrm{ha}^{-1}\right)+$ atrazine $\left(560 \mathrm{~g} \cdot \mathrm{ai} \cdot \mathrm{ha}^{-1}\right)$ controlled GR Canada fleabane 94, and 97\%, respectively, 8 WAA which was similar to saflufenacil/dimethenamid-p, mesotrione + atrazine and dicamba/atrazine. There was no treatment difference for corn yield. Based on these results, tolpyralate $\left(40 \mathrm{~g} \cdot \mathrm{ha}^{-1}\right)$, tolpyralate $\left(30 \mathrm{~g} \cdot \mathrm{ha}^{-1}\right)+$ atrazine and tolpyralate $(40$ $\left.\mathrm{g} \cdot \mathrm{ha}^{-1}\right)+$ atrazine, applied PRE, provided similar control of GR Canada flea-
\end{abstract}


bane as current industry standards at 8 WAA.

\section{Keywords}

Crop Injury, Density, Efficacy, Glyphosate-Resistant, Horseweed, Marestail, Residual Weed Control, Sensitivity, Weed Control g.ai $\cdot$ ha $^{-1}$

\section{Introduction}

Canada fleabane [Conyza canadensis (L.) Cronq.] is a widely adapted broadleaf weed that is native to North America [1]. As a summer or winter annual, Canada fleabane has become a troublesome agricultural weed. Germination of seeds can occur throughout the year if temperatures reach the base temperature for germination $\left(8.0^{\circ} \mathrm{C}-9.5^{\circ} \mathrm{C}\right)$ and flowering occurs throughout the summer and the latter part of the fall [2]. Seeds that germinate in the fall and over-winter as rosettes establish without competition from neighbouring weeds, which is a competitive advantage over other summer annual weeds [1]. Repeated applications of glyphosate have been used for control of Canada fleabane in no-till glyphosate-resistant (GR) cropping systems; this may have contributed to the evolution of GR Canada fleabane biotypes [3]. The first confirmed GR Canada fleabane population was discovered in 2001 in a GR soybean field near Delaware, USA that received glyphosate applications for three consecutive years [4]. In 2010, the first GR Canada fleabane population was discovered in Ontario in Essex County, and by 2015, GR populations were found in 30 counties across southern Ontario from the Michigan to the Quebec border [5].

Corn is sensitive to weed interference, especially during early stages of crop growth. In early stages of corn development, weed interference can lead to a decrease in corn dry matter and grain yield [6]. The critical weed-free period (CWFP) represents the time period where weed control is essential to prevent unacceptable yield loss (5\% - 20\%) [7]; they are crop specific and can vary yearly, across locations, soil types, climate, and weed species and density [8]. Hall et al. (1992) [9] estimated the CWFP for corn in Ontario to be from the 3 to 14 leaf-tip stage. Left uncontrolled, it has been reported from a study completed in Ontario, that GR Canada fleabane cause corn grain yield losses of up to $69 \%$ [10]. Control of GR Canada fleabane throughout this period is essential to prevent unacceptable yield loss due to weed interference.

Tolpyralate is an inhibitor of the 4-hydroxyphenyl-pyruvate dioxygenase (HPPD) enzyme and is the second benzoylpyrazole corn herbicide available for control of weeds. Compared to other Group 27 herbicides, tolpyralate provides equivalent or improved control of some annual broadleaf and grass weed species [11]. Atrazine is the recommended tankmix partner to accelerate the speed of weed control, to enhance weed control efficacy, and to enlarge the scope of weeds controlled [11] [12] [13]. Tolpyralate plus atrazine, applied POST, is effi- 
cacious on a number of annual grass and broadleaf weed species [11] [12]. The Canadian label claims control of 13 broadleaf and 5 grass weed species, however, Canada fleabane is not included on the label [13]. Previous research by Metzger et al. [11] [12] reported that tolpyralate + atrazine $\left(22.3+741.7 \mathrm{~g} \cdot \mathrm{ai} \cdot \mathrm{ha}^{-1}\right)$ was efficacious on Canada fleabane, which is lower than the labelled rate. The residual activity of tolpyralate + atrazine has not been explored, particularly for the control of GR Canada fleabane under Ontario environmental conditions. Therefore, the objective of this research was to determine if tolpyralate plus atrazine provides full-season residual control of GR Canada fleabane in corn.

\section{Materials and Methods}

Five field research trials were conducted in 2018 and 2019 at sites with confirmed GR Canada fleabane located near Dresden, Thamesville, Harrow, Ridgetown and Zone Centre, Ontario; all sites were managed no-till. Table 1 lists GR Canada fleabane sites, corn planting, corn emergence, and herbicide application dates. Nutritional needs of the crop and soil tests determined fertilizer applications. DKC45-65 RIB corn (Monsanto Co., St. Louis, MO) was seeded at approximately 83,000 seeds $\mathrm{ha}^{-1}$ at depths of $4 \mathrm{~cm}$ in rows spaced $76 \mathrm{~cm}$ apart. The trial was established in the field as a randomized complete block design with four replicates.

Following planting, the experimental area was sprayed with glufosinate (2000 g.ai $\cdot \mathrm{ha}^{-1}$ ) to remove all emerged Canada fleabane. The removal of all emerged GR Canada fleabane ensured that all herbicide efficacy ratings evaluated only the residual activity of the herbicide treatments applied. Herbicide treatments were applied with a $\mathrm{CO}_{2}$ pressurized backpack sprayer calibrated to deliver $200 \mathrm{~L} \cdot \mathrm{ha}^{-1}$ at $240 \mathrm{kPa}$ equipped with a $1.5 \mathrm{~m}$ handheld boom. The boom was equipped with four ULD12002 nozzles (Pentair, New Brighton, MN, USA) spaced $50 \mathrm{~cm}$ apart producing a spray width of $2 \mathrm{~m}$. Herbicides were applied preemergence (PRE) 1 - 3 days after planting. The weed-free control (WFC) plots received a treatment of saflufenacil/dimethenamid-p (735 g.ha $\left.{ }^{-1}\right)$ and subsequent hand removal of weeds if necessary throughout the season. Treatments

Table 1. Year, location, planting dates, emergence dates and herbicide application dates for six trials on control of glyphosate-resistant Canada fleabane in corn with tolpyralate plus atrazine in Ontario in 2018 and 2019.

\begin{tabular}{cccccc}
\hline & Year & $\begin{array}{c}\text { Nearest } \\
\text { Town }\end{array}$ & $\begin{array}{c}\text { Planting } \\
\text { Date }\end{array}$ & $\begin{array}{c}\text { Crop Emergence } \\
\text { date }\end{array}$ & $\begin{array}{c}\text { Herbicide } \\
\text { Application Date }\end{array}$ \\
\hline State & 2018 & Ridgetown & May 9 & May 20 & May 11 \\
& 2018 & Thamesville & May 9 & May 20 & May 11 \\
& 2018 & Harrow & May 25 & May 31 & May 25 \\
& 2019 & Zone Centre & May 22 & May 29 & May 24 \\
& 2019 & Ridgetown & May 24 & May 30 & May 24 \\
\hline
\end{tabular}


included tolpyralate applied at $30 \mathrm{~g}$ and $40 \mathrm{~g} \cdot \mathrm{ai} \cdot \mathrm{ha}^{-1}$, atrazine $\left(560 \mathrm{~g} \cdot \mathrm{ai} \cdot \mathrm{ha}^{-1}\right)$ and tolpyralate + atrazine at each rate and compared to three current industry standards for GR Canada fleabane control in corn: saflufenacil/dimethenamid-p (735 g.ai ha $\left.{ }^{-1}\right)$; mesotrione + atrazine (140 g.ai $\left.\cdot \mathrm{ha}^{-1}+1500 \mathrm{~g} \cdot \mathrm{ai} \cdot \mathrm{ha} \mathrm{a}^{-1}\right)$; and dicamba/ atrazine (1800 g.ai ha $\left.{ }^{-1}\right)$ [14]. Glyphosate (450 g.ae.ha $\left.{ }^{-1}\right)$ was applied POST to remove all other competing weeds and glyphosate-susceptible Canada fleabane biotypes. Corn injury was assessed at 1,2 and 4 weeks after emergence (WAE) of crop, and visible weed control at 2, 4 and 8 WAA and 12 WAA was assessed visually on a percent scale where 0 indicates no corn injury/weed control and 100 complete plant death. Canada fleabane density and dry biomass were determined by counting and cutting plants at the soil surface from two $0.25 \mathrm{~m}^{2}$ quadrats per plot, placing them in paper bag, drying the biomass to a constant mass at $60 \mathrm{C}$, and then weighing. Corn was harvested from two rows in each plot at maturity with a small plot combine; grain weight and moisture content were recorded. Corn grain yield is expressed as tonnes $\mathrm{ha}^{-1}$ and adjusted to $15.5 \%$ moisture before statistical analysis.

Data were subjected to analyses in SAS 9.4 (SAS Institute, Cary, NC) as a RCBD in the GLIMMIX procedure. Variance was partitioned into fixed effects, herbicide treatment, and random effects which were environment, replication within environment and the interaction between environment and herbicide treatment. Significance of effects was assessed using an F-test and Z-test, respectively. The Type 1 error rate was set at 0.05 . Control plots (weedy and weed-free control) were removed prior to analysis since there was no variance. All means were independently compared to zero to ascertain treatment differences to the weedy control. The appropriate distribution and link were assigned to each dependent variable to meet the assumptions of analyses that residuals have a mean of zero, are homogeneous and normally distributed. Inspection of the Shapiro-Wilk test and the scatterplots of studentized residuals determined the use of the arcsine square root transformation for weed control and lognormal transformation for density and biomass. Least-square means for all dependent variables were compared across treatments using a Tukey-Kramer test. Statistically significant differences were denoted by letter codes.

\section{Results and Discussion}

Corn injury was less than $10 \%$ with all treatments (data not presented). There was no treatment difference for corn yield (Table 2). Assessments 4 weeks after application (WAA) found tolpyralate $\left(30 \mathrm{~g} \cdot \mathrm{ai} \cdot \mathrm{ha}^{-1}\right)$, tolpyralate $\left(40 \mathrm{~g} \cdot \mathrm{a} \cdot \mathrm{ha} \mathrm{a}^{-1}\right)$, and atrazine (560 g.ai $\cdot \mathrm{ha}^{-1}$ ) controlled GR Canada fleabane 64, 78 and $72 \%$, respectively (Table 2). A tankmix of tolpyralate + atrazine at both rates improved GR Canada fleabane control to $94 \%$. Saflufenacil/dimethenamid-p, mesotrione + atrazine, and dicamba/atrazine controlled GR Canada fleabane 99, 95 and 92\%, respectively. At $8 \mathrm{WAA}$, tolpyralate $\left(30 \mathrm{~g} \cdot \mathrm{ai} \cdot \mathrm{ha}^{-1}\right)$, tolpyralate $\left(40 \mathrm{~g} \cdot \mathrm{ai} \cdot \mathrm{ha}^{-1}\right)$ and atrazine (560 g.ai.ha ${ }^{-1}$ ) controlled GR Canada fleabane 83,88 , and $83 \%$, respec- 
tively (Table 2). The tankmixes of tolpyralate $\left(30\right.$ g.aihha $\left.{ }^{-1}\right)+$ atrazine $(560$ g.ai $\left.\cdot \mathrm{ha}^{-1}\right)$ and tolpyralate $\left(40 \mathrm{~g} \cdot \mathrm{ai} \cdot \mathrm{ha}^{-1}\right)+$ atrazine $\left(560 \mathrm{~g} \cdot \mathrm{ai} \cdot \mathrm{ha} \mathrm{a}^{-1}\right)$ controlled GR Canada fleabane 94 , and $97 \%$, respectively 8 WAA which was similar to saflufenacil/dimethenamid-p, mesotrione + atrazine and dicamba/atrazine.

Late emerging GR Canada fleabane were variable in emergence timing and population density across trial sites. Tolpyralate, applied PRE, controlled GR Canada fleabane $<80 \%$ at 4 WAA (Table 2). Brown et al. 2016 [14] reported atrazine, applied PRE, controlled GR Canada fleabane $<50 \%$ in corn. The inclusion of atrazine with tolpyralate, applied PRE, improved control of GR Canada fleabane to $94 \%$, equivalent to the control achieved with saflufenacil/ dimethenamid-p, mesotrione + atrazine and dicamba/atrazine. Metzger et al. 2019 [11] [12] found a tankmix with tolpyralate + atrazine, applied both PRE or POST, enhanced GR Canada fleabane control compared to tolpyralate alone. Tolpyralate $\left(40 \mathrm{~g} \cdot \mathrm{ai} \cdot \mathrm{ha} \mathrm{a}^{-1}\right)$, tolpyralate $\left(30 \mathrm{~g} \cdot \mathrm{ai} \cdot \mathrm{ha}^{-1}\right)+$ atrazine, tolpyralate $\left(40 \mathrm{~g} \cdot \mathrm{a} \cdot \mathrm{ha}^{-1}\right)+$ atrazine, saflufenacil/dimethenamid-p, mesotrione + atrazine and dicamba/atrazine all provided comparable control of GR Canada fleabane of 88 to $99 \%$ at 8 WAA. Brown et al. 2016 [14] found dicamba/atrazine, mesotrione + atrazine and saflufenacil/dimethenamid-p, applied PRE controlled GR Canada fleabane 99\%, 97\% and 97\% control, respectively which were the most efficacious herbicides in that study. This is also similar to research by Davis et al.

Table 2. Percent control 4 and 8 WAA, density and biomass 8 WAA and corn yield for glyphosate-resistant Canada fleabane in corn with tolpyralate, atrazine and the combination at both label rates applied PRE and current PRE herbicides for glyphosate-resistant Canada fleabane at various locations in Ontario, Canada during 2018 and $2019^{\mathrm{a}}$.

\begin{tabular}{|c|c|c|c|c|c|c|}
\hline \multirow[t]{2}{*}{ Treatment $^{\mathrm{b}}$} & \multirow{2}{*}{$\begin{array}{c}\text { Rate } \\
\left(\mathrm{g} \cdot \mathrm{ai}^{\left.-\mathrm{ha}^{-1}\right)}\right.\end{array}$} & \multicolumn{2}{|c|}{$\begin{array}{l}\text { Visible Weed } \\
\text { Control (\%) }\end{array}$} & \multirow{2}{*}{$\begin{array}{c}\text { Weed } \\
\text { density } \\
\text { (no. } \mathrm{m}^{-2} \text { ) }\end{array}$} & \multirow{2}{*}{$\begin{array}{c}\text { Weed } \\
\text { Biomass } \\
\left(\mathrm{g} \cdot \mathrm{m}^{-2}\right)\end{array}$} & \multirow{2}{*}{$\begin{array}{c}\text { Yield } \\
\left(\mathrm{t} \cdot \mathrm{ha}^{-1}\right)\end{array}$} \\
\hline & & $4 \mathrm{WAA}$ & 8 WAA & & & \\
\hline Weedy $^{c}$ & & $0^{\mathrm{e}}$ & $0^{\mathrm{d}}$ & $30^{\mathrm{a}}$ & $11.8^{\mathrm{a}}$ & $10.5^{\mathrm{a}}$ \\
\hline Weed-free & & 100 & 100 & $0^{\mathrm{d}}$ & $0^{\mathrm{d}}$ & $12.4^{\mathrm{a}}$ \\
\hline Tolpyralate & 30 & $64^{\mathrm{d}}$ & $83^{\mathrm{b}}$ & $9^{\mathrm{ab}}$ & $5.7^{\mathrm{ab}}$ & $11.6^{\mathrm{a}}$ \\
\hline Tolpyralate & 40 & $78^{\mathrm{bcd}}$ & $88^{\mathrm{ab}}$ & $6^{\mathrm{b}}$ & $4.0^{\mathrm{abc}}$ & $11.5^{\mathrm{a}}$ \\
\hline Atrazine & 560 & $72^{\mathrm{cd}}$ & $83^{\mathrm{b}}$ & $9^{\mathrm{ab}}$ & $3.2^{\mathrm{abc}}$ & $11.8^{\mathrm{a}}$ \\
\hline Tolpyralate + Atrazine & $30+560$ & $94^{\mathrm{ab}}$ & $94^{\mathrm{ab}}$ & $4^{\mathrm{bc}}$ & $2.0^{\mathrm{bcd}}$ & $12.7^{\mathrm{a}}$ \\
\hline Tolpyralate + Atrazine & $40+560$ & $94^{\mathrm{ab}}$ & $97^{\mathrm{ab}}$ & $2^{\mathrm{bcd}}$ & $1.7^{\mathrm{bcd}}$ & $12.2^{\mathrm{a}}$ \\
\hline Saflufenacil/dimethenamid-p & 735 & $99^{\mathrm{a}}$ & $99^{a}$ & $1^{\mathrm{cd}}$ & $1.0^{\mathrm{cd}}$ & $11.6^{\mathrm{a}}$ \\
\hline Meostrione + atrazine & $140+1500$ & $95^{\mathrm{ab}}$ & $97^{\mathrm{ab}}$ & $3^{\mathrm{bcd}}$ & $1.2^{\mathrm{cd}}$ & $11.9^{\mathrm{a}}$ \\
\hline Dicamba/atrazine & 1800 & $92^{\mathrm{abc}}$ & $93^{\mathrm{ab}}$ & $4^{\mathrm{bc}}$ & $1.4^{\mathrm{bcd}}$ & $11.6^{\mathrm{a}}$ \\
\hline
\end{tabular}

a Means followed by the same letter within a column are not significantly different according to Tukey-Kramer's multiple range test $\alpha=0.05$. ${ }^{\text {All }}$ plots received a cover spray of glufosinate immediately after planting, 1 - 3 days prior treatment application. ${ }^{c}$ Weedy check only received cover spray of glufosinate $\left(2000 \mathrm{~g} \cdot \mathrm{ai}^{\mathrm{h}} \mathrm{ha}^{-1}\right)$. Means within column followed by the same letter are not statistically different according Tukey-Kramer's LSD $(\mathrm{P}=0.05)$. 
(2010) [15] that reported excellent control of GR Canada fleabane from spring applications of saflufenacil. The results from this research indicate that tolpyralate + atrazine, applied PRE, provides similar residual control of GR Canada fleabane to current industry standards in corn.

Tolpyralate (30 g.ai ha $\left.{ }^{-1}\right)$, and atrazine (560 g.ai ha $\left.{ }^{-1}\right)$, applied PRE, did not reduce GR Canada fleabane density, all other treatments reduced GR Canada fleabane density (Table 2). Tolpyralate (40 g.ai.ha $\left.{ }^{-1}\right)+$ atrazine, saflufenacil/dime-thenamid-p and mesotrione + atrazine reduced GR Canada fleabane density that it was similar to the extent of the weed-free control. Tolpyralate (30 or $40 \mathrm{~g} \cdot \mathrm{ai} \cdot \mathrm{ha}^{-1}$ ) and atrazine (560 g.ai.ha ${ }^{-1}$ ) did not reduce GR Canada fleabane biomass compared to the weedy control. Tolpyralate (30 or $40 \mathrm{~g} \cdot a \mathrm{i} \cdot \mathrm{ha}^{-1}$ ) + atrazine, saflufenacil/dimethenamid-p, mesotrione + atrazine and dicamba/atrazine reduced GR Canada fleabane biomass similarly, biomass was comparable to the weed-free control.

Density and biomass followed similar trends as control evaluations at 8 WAA. Density of GR Canada fleabane with tolpyralate (30 g.ai-ha $\left.{ }^{-1}\right)$ or atrazine (560 g.ai.ha $\left.{ }^{-1}\right)$ did not differ from the weedy control. Tolpyralate $\left(40 \mathrm{~g} \cdot \mathrm{ai} \cdot \mathrm{ha}^{-1}\right)$, tolpyralate $\left(30\right.$ g.ai $\left.\cdot \mathrm{ha}^{-1}\right)+$ atrazine and dicamba/atrazine reduced density $81 \%-88 \%$. Tolpyralate $\left(40 \mathrm{~g} \cdot \mathrm{ai} \cdot \mathrm{ha}^{-1}\right)+$ atrazine, saflufenacil/dimethenamid-p and mesotrione + atrazine reduced density $92-96 \%$, similar to the weed-free control. Similarily, Davis et al. 2010 [15] reported that saflufenacil reduced GR Canada fleabane densities by $90 \%$. Biomass of Canada fleabane was reduced $83 \%-91 \%$ by tolpyralate $\left(30\right.$ g.aiha $\left.{ }^{-1}\right)+$ atrazine, tolpyralate $\left(40 \mathrm{~g} \cdot \mathrm{ai} \cdot \mathrm{ha}^{-1}\right)+$ atrazine, salfufenacil/dimethenamid-p, mesotrione + atrazine and dicamba/atrazine which was similar to the weed-free control. Tolpyralate (30 and $40 \mathrm{~g} \cdot \mathrm{ai} \cdot \mathrm{ha}^{-1}$ ) and atrazine alone did not reduce GR Canada fleabane biomass and was similar to the weedy control. The findings from this research are consistent with Brown et al. 2016 [14] who observed significant reductions in GR Canada fleabane biomass and density from dicamba/atrazine, mesotrione + atrazine and saflufenacil/dimethenamid-p.

\section{Conclusion}

Based on these results, tolpyralate + atrazine, applied PRE, provides similar GR Canada fleabane control as the current industry standards. Glyphosate resistance and the extended GR Canada fleabane emergence pattern pose a challenge to corn producers. Early season applications of residual herbicides with activity on later emerging seedlings have been found to provide the most consistent control of GR Canada fleabane. Results from this research conclude that tolpyralate + atrazine provides residual control of GR Canada fleabane in corn through the critical weed-free period. HPPD-inhibiting herbicides, like tolpyralate, are one useful component in a diversified, integrated weed management program for optimal control of GR Canada fleabane in corn.

\section{Acknowledgements}

Funding for this project was provided in part by ISK Biosciences Inc. and Grain 
Farmers of Ontario (GFO).

\section{Conflicts of Interest}

The authors declare no conflicts of interest regarding the publication of this paper.

\section{References}

[1] Weaver, S.E. (2001) The Biology of Canadian Weeds. 115. Conyza canadensis. Canadian Journal of Plant Science, 81, 867-875. https://doi.org/10.4141/P00-196

[2] Tozzi, E., Beckie, H., Weiss, R., Gonzalez-Andujar, J.L., Storkey, J., Cici, S.Z. and Van Acker, R.C. (2014) Seed Germination Response to Temperature for a Range of International Populations of Conyza canadensis. Weed Research, 54, 178-185. https://doi.org/10.1111/wre.12065

[3] Nandula, V., Eubank, T., Poston, D., Koger, C. and Reddy, K. (2006) Factors Affecting Germination of Horseweed (Conyza canadensis). Weed Science, 54, 898-902. https://doi.org/10.1614/WS-06-006R2.1

[4] VanGessel, M. (2001) Glyphosate-Resistant Horseweed from Delaware. Weed Science, 49, 703-705. https://doi.org/10.1614/0043-1745(2001)049[0703:RPRHFD]2.0.CO;2

[5] Budd, C.M., Soltani, N., Robinson, D.E., Hooker, D.C., Miller, R.T. and Sikkema, P.H. (2018) Distribution of Glyphosate and Cloransulam-Methyl Resistant Canada Fleabane [Conyza canadensis (L.) Cronq.] in Ontario. Canadian Journal of Plant Science, 98, 492-497. https://doi.org/10.1139/CJPS-2016-0346

[6] Cerrudo, D., Page, E.R., Tollenaar, M., Stewart, G. and Swanton, C.J. (2012) Mechanisms of Yield Loss in Maize Caused by Weed Competition. Weed Science, 60, 225-232. https://doi.org/10.1614/WS-D-11-00127.1

[7] Swanton, C.J., Weaver, S., Cowan, P., Van Acker, R., Deen, W. and Sheshta, A. (1999) Weed Thresholds: Theory and Applicability. Journal of Crop Production, 2, 9-29. https://doi.org/10.1300/J144v02n01 02

[8] Knezevic, S.Z., Evans, S.P., Blankenship, E.E., Van Acker, R.E. and Lindquist, J.L. (2002) Critical Period for Weed Control: The Concept and Data Analysis. Weed Science, 50, 773-786. https://doi.org/10.1614/0043-1745(2002)050[0773:CPFWCT]2.0.CO;2

[9] Hall, M.R., Swanton, C.J. and Anderson, G.W. (1992) The Critical Period of Weed Control in Grain Corn (Zea mays). Weed Science, 40, 441-447. https://doi.org/10.1017/S0043174500051882

[10] Ford, L., Soltani, N., Robinson, D.E., Nurse, R.E., McFadden, A. and Sikkema, P.H. (2014) Canada Fleabane (Conyza canadensis) Control with Preplant Applied Residual Herbicides Followed by 2,4-D Choline/Glyphosate DMA Applied Postemergence in Corn. Canadian Journal of Plant Science, 94, 1231-1237. https://doi.org/10.4141/cjps2013-403

[11] Metzger, B.A., Soltani, N., Raeder, A.J., Hooker, D.C., Robinson, D.E. and Sikkema, P.H. (2019) Effect of Hybrid Varieties, Application Timing, and Herbicide Rate on Field Corn Tolerance to Tolpyralate plus Atrazine. Weed Science, 67, 475-484. https://doi.org/10.1017/wsc.2019.34

[12] Metzger, B.A., Soltani, N., Raeder, A.J., Hooker, D.C., Robinson, D.E. and Sikkema, P.H. (2019) Multiple Herbicide-Resistant Horseweed (Conyza canadensis) Dose 
Response to Tolpyralate and Tolpyralate plus Atrazine and Comparison to Industry Standard Herbicides in Corn. Weed Technology, 33, 366-373.

https://doi.org/10.1017/wet.2019.20

[13] Anonymous (2019) SHIELDEX ${ }^{\oplus}$ 400SC Herbicide Label. ISK Biosciences Corporation, Concord.

[14] Brown, L.R., Shropshire, C. and Sikkema, P.H. (2016) Control of Glyphosate-Resistant Canada Fleabane in Corn with Preplant Herbicides. Canadian Journal of Plant Science, 96, 932-934. https://doi.org/10.1139/cjps-2016-0049

[15] Davis, V.M., Gibson, K.D., Bauman, T.T., Weller, S.C. and Johnson, W.G. (2009) Influence of Weed Management Practices and Crop Rotation on Glyphosate-Resistant Horseweed (Conyza canadensis) Population Dynamics and Crop Yield-Years III and IV. Weed Science, 57, 417-426. https://doi.org/10.1614/WS-09-006.1 